\title{
The Comparison of Innovative Technology Usage Levels of Dairy Farms Supported and Non-Supported by IPARD Program; A Case Study of Konya
}

\author{
Aykut Örs ${ }^{1 *}$, Cennet Oğuz ${ }^{2}$ \\ ${ }^{1}$ Agriculture and Rural Development Institute Konya Provincial Coordination Unit, 42110 Selçuklu/Konya, Turkey \\ ${ }^{2}$ Department of Agricultural Economics, Faculty of Agriculture, Selçuk University, 42130 Konya, Turkey
}

\section{A R T I C LE INFO}

\section{Research Articles}

Received 25 July 2018

Accepted 01 October 2018

Keywords:

Innovative technology usage

Dairy farming

IPARD program

Supporting systems

Konya

"Corresponding Author:

E-mail: aykut.ors@tkdk.gov.tr
A B S T R A C T

The purpose of this study is to compare innovative technology usage levels of dairy farms, supported and non-supported by The Instrument for Pre-accession AssistanceRural Development (IPARD) program, by scoring their usage level of 10 innovative technologies in their dairy farms. Another purpose of the study is to determine the factors associated with the innovative technology usage levels of dairy farms. The main material of the study is dairy farms supported and not supported by the IPARD program in Konya. Full count sampling method was used when determining the dairy farms supported by IPARD Program and Neyman allocation sampling method was used when determining the dairy farm non-supported by IPARD program. Research data were collected from 50 dairy farms supported by IPARD program and 100 dairy farms non-supported by IPARD program by administering a questionnaire filled during the face-to-face interviews conducted with each individual respondent. As a result of the study, it was determined that the average gross production values and gross profits of dairy farms supported by IPARD program were 4 times higher than those non-supported by IPARD program. While innovative technology usage level of dairy farms non-supported by IPARD program were entirely low level, $90 \%$ of dairy farms supported by IPARD program were high level. From the point of view of dairy farm scale, it was determined that innovative technology usage levels were high $(69.84 \%)$ in dairy farms that had 51 and more milking cows. As a result of chi-square independence test, statistically significant relationship was found between innovative technology usage level of dairy farm and 12 of 13 factors.

\section{IPARD Programından Destek Alan Süt İşletmeleri ile Destek Almayan İşletmelerin Yenilikçi Teknoloji Kullanım Düzeylerinin Karşılaştırılması; Konya İli Örneği}

M A K A L E B İ L G İ S İ

\section{Araştırma Makalesi}

Geliş 25 Temmuz 2018

Kabul 01 Ekim 2018

Anahtar Kelimeler:

Yenilikçi teknoloji kullanımı

Süt inekçiliği

IPARD programı

Destekleme sistemleri

Konya

*Sorumlu Yazar:

E-mail: aykut.ors@tkdk.gov.tr
Ö Z

Bu çalışmanın amacı; Katılım öncesi yardım aracı - kırsal kalkınma bileşeni (IPARD) programından destek alan ve almayan süt işletmelerinin halihazırda kullandıkları 10 yenilikçi teknolojinin kullanma düzeylerine göre puanlanarak, yenilikçi teknoloji kullanım düzeylerinin karşılaştırılmasıdır. İşletmelerin yenilikçi teknoloji kullanım düzeyleri ile ilişkili olan faktörlerin tespit edilmesi de çalışmanın bir diğer amacıdır. Araştırmanın ana materyalini, Konya ilinde IPARD desteği alan süt inekçiliği işletmeleri ile destekten yararlanmamış olan süt inekçiliği işletimleri oluşturmaktadır. Çalışma kapsamında; tam sayım yöntemi ile belirlenmiş IPARD'dan destek alan 50 işletme ile Neyman yöntemi ile belirlenmiş IPARD'dan destek almayan 100 işletmeden anket tekniğine göre veri toplanmıştır. Çalışma sonucunda IPARD'dan destek alan işletmelerin ortalama gayrisafi üretim değerlerinin ve brüt karlarının, destek almayanlara göre 4 kat daha fazla olduğu tespit edilmiştir. IPARD'dan destek almayan işletmelerin tamamı düşük düzeyde yenilikçi teknoloji kullanan işletmelerden oluşurken, IPARD'dan destek alan işletmelerin \%90'ının yüksek düzeyde yenilikçi teknoloji kullanan işletmeler olduğu belirlenmiştir. İşletme ölçeği açısından bakıldığında ise yüksek düzeyde yenilikçi teknoloji kullanım oranının 51 baş ve üzeri büyüklükteki işletmelerde yüksek olduğu $(\% 69,84)$ tespit edilmiştir. Ki-kare bağımsızlık testi sonucunda, süt inekçiliği işletmelerinde yenilikçi teknoloji kullanma düzeyi ile test edilen 13 faktörün 12'si arasında istatistiksel olarak anlamlı bir ilişki olduğu ortaya konmuştur. 


\section{Introduction}

For today's businesses, profitability, market share and competitiveness are essential for businesses to maintain their assets. However, sustainability of enterprises is only possible by constantly updating and improving themselves in macro and micro economic conditions. Innovation is an issue that must be emphasized in terms of businesses as it allows businesses to innovate themselves and thus to improve their products and services in the same direction (Bülbül, 2014). When we look at the types of innovation, innovation is classified as innovation in production process, innovation in marketing and organizational innovation (Anonymous, 2005). Innovation in the production process is at the forefront in dairy farms. The key element of innovation in the production process is innovative technology usage.

The purpose of this study is to compare innovative technology usage levels of dairy farms, supported and non-supported by The Instrument for Pre-accession Assistance-Rural Development (IPARD) program, by scoring their usage level of 10 innovative technologies in their dairy farms. Another purpose of the study is to determine the factors associated with the innovative technology usage levels of dairy farms.

\section{Material and Methods}

\section{Material}

As a research area, Konya province was selected according to "judgment sampling method". By the presence of cattle and milk production, Konya is the first province in Turkey. In Konya the cattle number was 740.148 head and milk production was 1.018.917 tons, according to TUIKK data of 2015. It is also one of the top three provinces, supported by IPARD program. The main material of the study is dairy farms supported and not supported by the IPARD program in Konya. Dairy farm data's were obtained through interviews. The interviews were conducted by face to face interview between dates May and November 2017. In addition to these data's, publications and web pages belonging to the relevant public institutions, previous research findings and published secondary data were used.

\section{Sampling Method}

During the study, there were 50 dairy farms supported by IPARD program and operating in Konya. Because the population was small and it was easy to reach the desired information, full count sampling method was used when determining the dairy farms supported by IPARD program. Simple random sampling method was used when determining the dairy farms non-supported by IPARD program.

According to IPARD program, milking cow number criteria for dairy farms is minimum 10 milking cows and maximum 120 milking cows. In accordance with this criteria; the main frame of dairy farms not supported by IPARD program was determined as 4.209 establishments in 16 districts of Konya which had milking cows between 10 to120 head. Neyman method from the stratified sampling method was used in the calculation of sample volume. According to the Neyman method, the equation that determines the sample volume was formulated as follows (Yamane, 1967).

$$
\mathrm{n}=\frac{\left[\sum\left(\mathrm{N}_{\mathrm{h}} \mathrm{S}_{\mathrm{h}}\right)\right]^{2}}{\mathrm{~N}^{2} \mathrm{D}^{2}+\sum\left[\mathrm{N}_{\mathrm{h}}\left(\mathrm{S}_{\mathrm{h}}\right)^{2}\right]}
$$

In formula; $\mathrm{n}=$ sample volume, $\mathrm{N}=$ total unit number belonging to the sampling frame, $\mathrm{D}=\mathrm{d} / \mathrm{t}, \mathrm{d}=$ derivation from the average, $\mathrm{t}=$ standard normal distribution value.

The sample volume was determined by using the number of milking cows. The sample size was calculated as 100 for a confidence interval of $95 \%$ and an error margin of $5 \%$. As a result 150 dairy farms were determined as total sample volume.

The sizes of the dairy farms were examined by arranging various strata and 3 strata were considered suitable considering the frequency distributions. These strata were determined as dairy farms which had 10 to 25 head, 26 to 50 head and 51 to 120 head milking cows.

The Method Used to Determine Innovative Technology Usage Levels of Dairy Farms

In order to demonstrate the innovative technology usage level of dairy farms, innovative technologies were identified first and each innovative technology was scored as 0 or 1 (Table 1). This scoring was converted to index by using below formula. By using this index, all dairy farms classified into two sub-groups named as "high level innovative technology users" and "low level innovative technology users" (Özkaya, 1996). Innovative technology usage index was calculated by using following formula;

$$
\text { Index }_{\text {itu }}=\frac{\text { T.S. of dairy farm }}{\text { M.S. the dairy farm can }} \times 100
$$

Index $\mathrm{itu}_{\mathrm{itu}}$ innovative technology usage index

T.S.: total score M.S. : maximum score

Table 1 Scoring of innovative technology usage

\begin{tabular}{l|cc}
\hline \multirow{2}{*}{\multicolumn{1}{c|}{ Innovative Technology }} & \multicolumn{2}{c}{ Score } \\
\cline { 2 - 3 } & $\mathrm{U}$ & $\mathrm{NU}$ \\
\hline Automatic milking system & 1 & 0 \\
Automatic waterer & 1 & 0 \\
Electronic animal tracking system & 1 & 0 \\
System for tracking individual milk yield of cows & 1 & 0 \\
Milk quality analyser & 1 & 0 \\
TMR: total mixed ration & 1 & 0 \\
Monitoring dairy cow activity* & 1 & 0 \\
Precision dairy technologies** & 1 & 0 \\
Milk cooling and storage tank & 1 & 0 \\
Manure waste management system & 1 & 0 \\
\hline Total & \multicolumn{2}{|c}{10} \\
\hline
\end{tabular}

U: Using, NU: Not using, *(Pedometer etc.), **(milking robots, feeding robots etc.)

Dairy farms which had less than $\% 50$ innovative technology usage index (ITUI) were classified as "low level innovative technology users", while dairy farms which had $\% 50$ or over innovative technology usage index (ITUI) were classified as "high level innovative technology users". 
The Method Used to Determine the Factors Associated with The Innovative Technology Usage Levels of Dairy Farms

It was analysed with chi-square independence test, whether there was a relationship between innovative technology usage level and certain factors. The chi-square test is based on whether the difference between the observed frequencies and the expected frequencies is significant. In other words, the chi-square test is used to control the accordance between a real distribution and a theoretical distribution. In the populations indicated by the census, the difference between two or more groups is determined by the chi-square test. The following formula is used to calculate the chi-square value.

In the formula $f$ is observed frequency and $f^{\prime}$ is expected frequency (Kabukçu, 1994).

$$
x^{2}=\sum \frac{\left(f-f^{\prime}\right)^{2}}{f^{\prime}}
$$

Chi-square test has three commonly used types which are goodness of fit test, homogeneity test and independence test. Independence test was used in this study. Chi-square independence test is being applied to examine whether there is independence between qualitative variables of two or more classes. Two way contingency tables, which are consist of horizontal (row) and vertical (column) bands to write observed frequencies of two variables examined, are being used (Özmen, 2009).

In this study, package software was used to apply chisquare independence test. Primarily, null hypothesis $\left(\mathrm{H}_{0}\right)$ and alternative hypotheses $\left(\mathrm{H}_{1}\right)$ were established. Then coding and frequency tables were created. Chi-square test was carried out by entering the data's to package software. When evaluating chi-square test results: $p$ value between 0.01 and 0.05 was evaluated as statistically significant; $p$ value between 0.001 and 0.01 was evaluated as statistically significant at high level; $p$ value below 0.001 was evaluated as statistically significant at very high level. If the result of chi-square test wasn't statistically significant, null hypothesis (H0) was accepted, otherwise alternative hypotheses (H1) was accepted.

\section{Research Findings}

\section{General Information on Dairy Farms Examined}

As a result of the data analysis in the research area, general information about dairy farms was presented in Table 2.

While the average number of milking cows for dairy farms non-supported by IPARD program was 30.65, it was 108.76 for dairy farms supported by IPARD program. The average animal unit of dairy farms supported by IPARD program was 4 times higher than those nonsupported by IPARD program. Dairy farms nonsupported by IPARD program had 49.80 animal unit and dairy farms supported by IPARD program had 156.71 animal unit. Considering the annual average lactation yield per dairy cow; while dairy farms non-supported by IPARD program had $7.489 .00 \mathrm{Kg}$ milk yield, dairy farms supported by IPARD program had $9.465 .86 \mathrm{Kg}$ milk yield. Gross production value, operating expense and gross profit average values were identified as 605.043.33 TL, 439.785.19 TL, 269.219.39 TL for dairy farms nonsupported by IPARD program and 333.759.38 TL, 1.549.309.09 TL, 1.164.025.91 TL for dairy farms supported by IPARD program, respectively. The average Gross production value, operating expense and gross profit values of dairy farms supported by IPARD program were 4 times higher than those non-supported by IPARD program.

Table 2 General information on dairy farms examined

\begin{tabular}{rc|rrrrrrr}
\hline \multicolumn{2}{c}{ DFG } & NDF & NLC & \multicolumn{1}{c}{ AU } & \multicolumn{1}{c}{ LY } & \multicolumn{1}{c}{ GPV } & \multicolumn{1}{c}{ OE } & GP \\
\hline \multirow{4}{*}{ NS } & $10-25$ & 63 & 15.57 & 26.85 & 7.302 .63 & 337.472 .62 & 256.452 .48 & 152.641 .04 \\
& $26-50$ & 20 & 36.00 & 53.44 & 7.616 .42 & 705.127 .88 & 502.685 .87 & 319.007 .08 \\
& $51-+$ & 17 & 80.24 & 130.56 & 8.030 .27 & 1.478 .882 .38 & 1.045 .193 .80 & 642.671 .30 \\
\cline { 2 - 9 } & T/A & 100 & 30.65 & 49.80 & 7.489 .09 & 605.043 .33 & 439.785 .19 & 269.219 .39 \\
\hline \multirow{4}{*}{ S } & $10-25$ & 2 & 18.00 & 35.44 & 6.975 .56 & 457.208 .00 & 316.048 .28 & 256.325 .50 \\
& $26-50$ & 2 & 38.50 & 46.39 & 10.310 .06 & 884.312 .50 & 717.586 .96 & 399.374 .00 \\
& 51-+ & 46 & 115.76 & 170.03 & 9.537 .43 & 2.478 .368 .00 & 1.639 .090 .96 & 1.236 .736 .88 \\
\hline
\end{tabular}

DFG: Dairy Farm Groups (head), NS: Dairy farms non-supported by the IPARD program, S: Dairy farms supported by the IPARD program, NDF: Number of Dairy Farms, NLC: Number of Lactating Cows, AU: Animal Unit, LY: Lactation Yield (Kg/head), GPV: Gross Production Value (TL), OE: Operating Expense (TL), GP: Gross Profit (TL), T/A: Total / Average

Innovative Technology Usage Levels of Dairy Farms Examined

Innovative technology usage score and index values were presented according to state of benefiting from IPARD support and farm size in Table 3. According to Table 3, Innovative technology usage index was increased in both groups by increase of farm size. The average values of innovative technology usage index of dairy farms non-supported by IPARD program were 9.84 for 10-25 head milking cow sized farms, 19.00 for $26-50$ head milking cow sized farms and 30.00 for 51 head and above milking cow sized farms. And for dairy farms supported by IPARD program, the average values of innovative technology usage index were 40.00 for $10-25$ head milking cow sized farms, 60.00 for 26-50 head milking cow sized farms and 78.26 for 51 head and above milking cow sized farms. The general average value of innovative technology usage index for dairy farms nonsupported by IPARD program was 15.10 , while it was 76.00 for dairy farms supported by IPARD program. 
Table 3 Innovative technology usage score and index value

\begin{tabular}{|c|c|c|c|c|c|c|c|c|}
\hline \multirow{2}{*}{ Innovative Technology } & \multicolumn{4}{|c|}{ NS } & \multicolumn{4}{|c|}{$\mathrm{S}$} \\
\hline & $10-25$ & $26-50$ & $51-+$ & $\mathrm{A}$ & $10-25$ & $26-50$ & $51-+$ & A \\
\hline Automatic milking system & 0.11 & 0.35 & 0.88 & 0.29 & 1.00 & 1.00 & 1.00 & 1.00 \\
\hline Automatic waterer & 0.33 & 0.75 & 1.00 & 0.53 & 1.00 & 1.00 & 1.00 & 1.00 \\
\hline Electronic animal tracking system & 0.00 & 0.00 & 0.00 & 0.00 & 0.00 & 0.50 & 0.87 & 0.82 \\
\hline System for tracking individual milk yield of cows & 0.16 & 0.15 & 0.12 & 0.15 & 0.00 & 0.50 & 0.87 & 0.82 \\
\hline Milk quality analyser & 0.02 & 0.00 & 0.00 & 0.01 & 0.00 & 0.50 & 0.93 & 0.88 \\
\hline TMR: total mixed ration & 0.00 & 0.00 & 0.00 & 0.00 & 0.00 & 0.00 & 0.22 & 0.20 \\
\hline Monitoring dairy cow activity* & 0.00 & 0.00 & 0.00 & 0.00 & 0.00 & 0.50 & 0.89 & 0.84 \\
\hline Precision dairy technologies $* *$ & 0.00 & 0.00 & 0.00 & 0.00 & 0.00 & 0.00 & 0.07 & 0.06 \\
\hline Milk cooling and storage tank & 0.37 & 0.65 & 1.00 & 0.53 & 1.00 & 1.00 & 1.00 & 1.00 \\
\hline Manure waste management system & 0.00 & 0.00 & 0.00 & 0.00 & 1.00 & 1.00 & 0.98 & 0.98 \\
\hline Total Score & 0.98 & 1.90 & 3.00 & 1.51 & 4.00 & 6.00 & 7.83 & 7.60 \\
\hline Innovative technology usage index & 9.84 & 19.00 & 30.00 & 15.10 & 40.00 & 60.00 & 78.26 & 76.00 \\
\hline
\end{tabular}

NS: Dairy farms non-supported by the IPARD program, S: Dairy farms supported by the IPARD program, A: Average, *(Pedometer etc.), **(milking robots, feeding robots etc.)

Table 4 Innovative technology usage levels

\begin{tabular}{|c|c|c|c|c|c|c|}
\hline \multirow{2}{*}{ Dairy Farm Groups } & \multicolumn{2}{|c|}{$\mathrm{L}$} & \multicolumn{2}{|c|}{$\mathrm{H}$} & \multicolumn{2}{|c|}{ Total } \\
\hline & NDF & $\%$ & NDF & $\%$ & NDF & $\%$ \\
\hline Dairy farms non-supported by the IPARD program & 100 & 100.00 & 0 & 0.00 & 100 & 100.00 \\
\hline Dairy farms supported by the IPARD program & 5 & 10.00 & 45 & 90.00 & 50 & 100.00 \\
\hline $10-25$ head & 65 & 100.00 & 0 & 0.00 & 65 & 100.00 \\
\hline 26-50 head & 21 & 95.45 & 1 & 4.55 & 22 & 100.00 \\
\hline 51 and above head & 19 & 30.16 & 44 & 69.84 & 63 & 100.00 \\
\hline Total & 105 & 70.00 & 45 & 30.00 & 150 & 100.00 \\
\hline
\end{tabular}

L: Low level innovative technology users, H: High level innovative technology users, NDF: Number of Dairy Farms

The first three innovative technologies that received the highest score in dairy farms non-supported by IPARD program were milk cooling and storage tank (0.53), automatic waterer $(0.53)$ and automatic milking system (0.29). The first three innovative technologies that received the highest score in dairy farms supported by IPARD program were the same, and these technologies received a full score.

Innovative technology usage levels were presented according to state of benefiting from IPARD support and farm size in Table 4 . While 70 percent of dairy

farms in the research area were low level innovative technology users, 30 percent of dairy farms were high level innovative technology users.

All dairy farms non-supported by IPARD program were low level innovative technology users. 90 percent of dairy farms supported by IPARD program were high level innovative technology users while 10 percent of them were low level innovative technology users.

According to farm sizes, 100 percent of 10-25 head milking cow sized farms, 95.45 percent of 26-50 head milking cow sized farms and 30.16 percent of 51 head and above milking cow sized farms were low level innovative technology users. In another saying, high level innovative technology users were 4.55 percent of 26-50 head milking cow sized farms and 69.84 percent of 51 head and above milking cow sized farms.

\section{Chi-square Independence Test}

Factors affecting the adaptations of innovations were discussed in three groups as socio-economic characteristics, personal variables and communication behaviors in Roger's (1983) book of "Diffusion of Innovations".
Base on this grouping, Chi-Square Independence Test was used to determine whether the relationship between innovative technology usage level and some factors was statistically significant. These factors were farm size, age of farmer, graduation, experience, membership of the producer group, frequency of using mass media, frequency of visiting technical staff, participation in fairs, commercial production, level of gross profit, level of gross production value and level of labor usage. Results of Chi-Square Independence Test were given in Table 5.

According to Chi-Square Independence Test results, the relationship between innovative technology usage level and farm size, graduation, experience, frequency of using mass media, frequency of visiting technical staff, participation in fairs, commercial production, level of gross profit, level of gross production value and level of labor usage was statistically significant at a very high level $(\mathrm{p}<0.001)$. The relationship between innovative technology usage level and age of farmer was statistically significant $(\mathrm{p}<0.05)$. There was no statistically significant relationship between innovative technology usage level and membership of the producer organization group.

\section{Conclusion and Recommendations}

As a result of study, it was determined that the average of milking cow number and lactation milk yield were much higher in dairy farms supported by IPARD program than those non-supported by IPARD program. Accordingly, the average gross production value and gross profits of dairy farms supported by IPARD program were four times higher than those non-supported by IPARD program. 
Tablo 5 Results of chi-square independence test

The factors compared with the innovative technology usage levels of dairy farms

IPARD support (1-supported, 2- non-supported)

Farm size (1- 10-25, 2- 26-50, 3- 51 and above heads)

Age of farmer/operator (1- young farmer under the age of 40, 2- farmer above the age of 40)

Graduation (1- above elementary school, 2- elementary school and below)

Experience (1- 5 year and above, 2- below 5 year)

Membership of the producer group (1- member, 2- not member)

Frequency of using mass media (1- frequent, 2- rare

Frequency of visiting technical staff (1- frequent, 2- rare

Participation in fairs (1- participating 2- not participating)

Commercial production (1- commercial 2- non-commercial)

Level of gross profit (1- high level, 2- low level)

Level of gross production value (1- high level, 2- low level)

Level of labor usage (1- high level, 2- low level)

$* \mathrm{P}<0.05, * * \mathrm{P}<0.01, * * * \mathrm{P}<0.001$

While all of the dairy farms non-supported by IPARD program were low level innovative technology users, 90 percent of dairy farms supported by IPARD program were high level innovative technology users.

The most important reason why this ratio is high in dairy farms supported by IPARD program was obligation to have automatic milking system, milk quality analyzer, milk cooling and storage tank, manure waste management system (for certain animal number). Another reason was investing in innovative technologies and modernizing their farms at a much lower cost by taking advantage of the grant opportunity.

According to farm size, while there was no high level innovative technology users in 10-25 head milking cow sized farm, 4.55 percent of 25-50 head milking cow sized farms were high level innovative technology users. It was observed that the level of innovative technology usage was high in 51 head and above sized farms at a percentage of 69.84

As a result of the Chi-Square Independence Test, frequencies of factors with statistically significant relation with the level of innovative technology usage were examined. According to this, dairy farms supported by IPARD program; 51 head and above sized farms; farms that using mass media less frequently, visiting technical staff more frequently, participating in fairs, making commercial production, having high gross profit, having high gross production value, having high labor usage; farmers that under the age of 40, graduated above elementary school and had 5 year experience or above were more likely to use innovative technology.

\section{Acknowledgements}

This article has been prepared by using the PhD dissertation entitled "Impact of IPARD Program on Competiveness of Dairy Farms in Konya" and the TUBİTAK project numbered 116K697.

\section{References}

Anonymous. 2005. Oslo Manual-Guidelines for Collecting and Interpreting Innovation Data: Proposed Guidelines for Collecting and Interpreting Innovation Data. Organisation for Economic Cooporation and Development. ISBN: 9264013083.
Boz İ. 2014. Determination of best management practices and innovations in beef cattle farming and their adoption in the Eastern Mediterranean Region of Turkey. Bulgarian Journal of Agricultural Science, 20(3): 552-562. Available from: https://www.agrojournal.org/ [23 September 2018]

Bülbül ME. 2014. İnovasyon performans1 değerlendirme sürecinde AHS ve GIA bütünleşik yaklaşımı: süt ürünleri sektöründe bir uygulama. Yüksek Lisans Tezi. Osmangazi Üniversitesi Sosyal Bilimler Enstitüsü, Eskişehir.

Dimara E, Skuras D. 2002. Adoption of agricultural innovations as a two-stage partial observability process. Agriculturul Economics, 28 (3): 187-196. DOI: https://doi.org/10.1016/ S0169-5150(03)00003-3.

Feder G, Umali DL. 1993. The adoption of agricultural innovations, Technological Forecasting and Social Change, 43: 215-239. DOI: https://doi.org/10.1016/0040-1625(93)90053-A

Kabukçu MA. 1994. Sağlık sosyal ve fen bilimlerinde uygulamalı istatistik. Merhaba Ofset, Konya. 175-176.

Özkaya T. 1996. Tarımsal yayım ve haberleşme. 1. Basım. Ege Üniversitesi Ziraat Fakültesi Yayınları, İzmir. Yayın No: 520.

Özmen A. 2009. İstatistik. TC Anadolu Üniversitesi Yayınları, Eskişehir. Yayın No:1448.

Rogers EM. 1983. Diffusion of innovations. 3th Edition. The Free Press, New York.

Sezgin A, Kaya ET, Külekçi M, Kumbasaroğlu H. 2010. Tarımsal yeniliklerin benimsenmesinde etkili olan faktörlerin analizi: Erzurum ili örneği. Türkiye IX. Tarım Ekonomisi Kongresi, Şanlıurfa. 22-24 September 2010.

Türkyılmaz MK, Bardakçıoğlu HE, Nazlıgül A. 2002, Aydın ili süt sığırcılığı işletmelerinde yeniliklerin benimsenmesine etkili olan sosyo-ekonomik faktörler. Turk J. Vet. Anim. Sci., 27(6), 1269-1275.

Yamane T. 1967. Elementery sampling theory prentice inc. Englewood Cliffs, USA.

Yener A. 2013. Konya ili Ereğli ilçesi süt işletmelerinin ekonomik faaliyetleri ve yenilikleri benimseme düzeyleri. Yüksek Lisans Tezi. Selçuk Üniversitesi, Fen Bilimleri Enstitüsü, Konya.

Yılmaz F. 2008. Osmaniye ili Düziçi ilçesinde hayvancılık yapan tarim işletmelerinde yeniliklerin benimsenmesi ve yayılmasında kooperatiflerin rolü. Yüksek Lisans Tezi. Çukurova Üniversitesi, Fen Bilimler Enstitüsü, Adana.

Yüksel M. 2009. Köy-Koop.'a üye olan ve süt sığırcılığı yapan işletmeler ile üye olmayıp süt sığırcılığı yapan işletmelerin tarımsal yeniliklerin benimsenmesi açısından karşılaştırılması. Yüksek Lisans Tezi. Çanakkale Onsekiz Mart Üniversitesi, Fen Bilimler Enstitüsü, Çanakkale. 